Human and Animal Health

Vol.59: e16150775, January-December 2016 http://dx.doi.org/10.1590/1678-4324-2016150775 ISSN 1678-4324 Online Edition

BRAZILIAN ARCHIVES OF BIOLOGY AND TECHNOLOGY

AN INTERNATIONAL JOURNAL

\title{
Clotting and fibrinogenolysis inhibition by essential oils from species of the Asteraceae family
}

\author{
Cíntia Alvarenga Santos Fraga de Miranda ${ }^{1}$, Maria das Graças Cardoso $^{1 *}$; Silvana \\ Marcussi $^{1}$ and Maria Luisa Teixeira ${ }^{1}$. \\ ${ }^{1}$ Universidade Federal de Lavras, Química, Lavras, Brasil.
}

\begin{abstract}
Essential oils are pharmacologically active and unexplored compounds. The inhibitory properties of essential oils from Baccharis dracunculifolia, Conyza bonariensis, Tithonia diversifolia and Ambrosia polystachya were evaluated in the coagulation and fibrinogenolysis induced by snake venoms. The essential oil from Conyza bonariensis extended the clotting time of Lachesis muta from 52.2 to 115.2 seconds and that of Bothrops moojeni from 108.3 to 2340.0 seconds, when pre-incubated with the venoms. The longest clotting times for Bothrops atrox venom were observed after incubation with the essential oils from Conyza bonariensis and Tithonia diversifolia: the times increased from 100.8 to 264.0 and 227.7 seconds, respectively. The prior incubation of the essential oils with plasma and subsequent addition of Lachesis muta venom resulted in a pro-clotting effect. The oils from Ambrosia polystachya and Baccharis dracunculifolia caused $100 \%$ of inhibition on the fibrinogenolysis induced by Bothrops moojeni and Lachesis muta venoms (the oils were previously incubated with the venom). The results indicate that the essential oils show promise as adjuvants for the treatment of snakebites.
\end{abstract}

Key-words: Proteases inhibitors, Baccharis dracunculifolia, Conyza bonariensis, Tithonia diversifolia, Ambrosia polystachya.

*Authors for correspondence: mcardoso@dqi.ufla.br 


\section{INTRODUCTION}

Snake venoms are complex combinations of several proteins (mostly enzymes), peptides, nucleotides, free amino acids, biogenic amines, some lipids, and several ions capable of inducing physiopathologies characteristic of each species. Venoms generally produce local effects such as hemorrhage, necrosis, edema and intense pain, and systemic effects such as bleeding disorders, cardiovascular shock and acute renal failure ${ }^{1}$. Snake venoms present different actions that depend on the specific combinations of their components, such as phospholipases $\mathrm{A}_{2}$, serineproteases, metalloproteinases, hyaluronidases and L-amino acid oxidases ${ }^{2}$.

Annually, about 40,000 people die of snakebites worldwide, including about 25,000 in India, 10,000 in the United States and the rest in other countries ${ }^{3}$. In Brazil, accidents with snakes of the Bothrops genus (Viperidae), widely distributed throughout the national territory, stand out in number and severity, being of great relevance because of permanent sequels characterized mainly by the loss of the affected limb ${ }^{4}$. The snakes of the Lachesis genus (Viperidae) are also relevant because of the severity of the local effects induced by their venoms, although they have a geographical distribution restricted to the Amazon basin (Lachesis muta muta L.) and the Atlantic forest, from north of Rio de Janeiro to Paraiba (Lachesis muta rhombeata L.) $)^{5}$.

The search for new inhibitors of isolated toxins and snake venoms is essential to complement or even to replace serotherapy, because this type of therapy is not very effective in neutralizing the local effects observed after snakebites and it is not very accessible to high-risk areas. The popular use of medicinal plants for the treatment of snakebites has been consecrated because they have a broad spectrum of effects $6,7,8,9,10$. This fact emphasizes the economic and medical importance of ethnopharmacological studies that evaluate the therapeutic properties of plant species. These studies have been exploring the possibility of using plant extracts and isolated active principles for the inhibition of clotting/hemorrhage, inflammation, myotoxicity, edema, and cardiotoxicity, among others. The active components derived from plants usually act as enzyme inhibitors, inactivating chemicals or immunomodulation agents capable of interacting with macromolecules present in the venoms from different species of snakes or with target molecules belonging to the animal organism ${ }^{7}$.
Some of the tests used to evaluate the inhibitory potential of plant compounds against snake venoms are the determination of the effects on blood clotting and fibrinogenolysis. Proteases (serine and metalloproteinases) are the principal enzymes responsible for these activities, being involved in

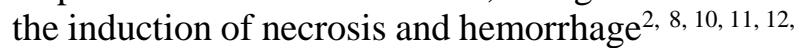
13

A review on medicinal plants reported nine plant species from the Asteraceae family (Baccharis sp., Bidens pilosa L., Calendula officinalis L., Clibadium sylvestre (Aubl.) Baill., Cynarasco lymus L., Eclipata prostata L., Lychnophora pinaster Mart., Mikania glomerata Spreng. and Solidago chilensis Meyen) with inhibitory properties against snake venoms ${ }^{14}$. The plants are potential inhibitors of toxic and pharmacological effects induced mainly by phospholipases $\mathrm{A}_{2}$ and proteases present in snake venoms from some genus of the Viperidae family such as Bothrops, Crotalus, Agkistrodon, Echis and Calloselasma. No studies of this nature have been performed with the extracts or essential oils from the plant species evaluated in the present work.

Although consisting of a wide variety of molecules with pharmacological properties, scientific studies reporting the antiophidian properties of essential oils are scarce. The inhibitory properties of ethanolic extracts and the essential oil extracted from the leaves of Nectandra angustifolia (Schrad.) Nees. (Lauraceae) on clotting and the hemolysis induced by the Bothrops neuwiedi Wagler (Viperidae) venom were reported ${ }^{13}$. In addition, Miranda et al. (2014) ${ }^{15}$ reported the inhibitory effect of the essential oil from Hedychium coronarium on fibrinogenolysis and clotting induced by Bothrops and Lachesis snake venoms.

The chemical composition of essential oils is characteristic to each species, presenting a biological function vital to the survival and adaptation of the plants to the environment. Even though they are complex mixtures of chemicals, phenylpropanoids and terpenoids predominate in their compositions, and, within this last class, the monoterpenes are the compounds found in greater proportion in essential oils, followed by sesquiterpenes. The combination of constituents of each essential oil is related to its pharmacological properties ${ }^{16}$. Among the plants producing essential oils, the Asteraceae family has been widely explored because it is the largest systematic group of Angiosperms, comprising about 1,100 genera and 25,000 species $^{17}$. Considering the wide 
applicability of secondary metabolites present in essential oils in pharmaceutical, cosmetic and food sciences, and the scarcity of studies on antiophidian properties, a new and promising line of research to be explored is the pharmacological characterization of these oils with a view to the development of products for the treatment of snakebites. Therefore, the aim of this study was to assess the inhibitory properties of essential oils extracted from the leaves of four species of the Asteraceae family [Baccharis dracunculifolia DC., Conyza bonariensis (L.) Cronquist, Tithonia diversifolia (Hemsl.) A. Gray and Ambrosia polystachya DC.] on the coagulating and fibrinogenolysis activities induced by Lachesis muta L., Bothrops atrox L. and Bothrops moojeni snake venoms.

\section{MATERIAL AND METHODS}

Plant material and isolation of the essential oils The rib and limbo of young leaves $(900 \mathrm{~g})$ from adult plant species (Baccharis dracunculifolia, Conyza bonariensis, Tithonia diversifolia and Ambrosia polystachya) belonging to the Asteraceae family were collected at approximately 8:00 a.m. on the Campus of the Universidade Federal de Lavras (UFLA) (latitude $21^{\circ} 14^{\prime} \mathrm{S}$, longitude $45^{\circ} 00^{\prime} \mathrm{W}$ Gr. and $918 \mathrm{~m}$ in altitude) on days without precipitation in February 2012. Species identification was kindly performed by Doctor Mariana Esteves Mansanares, Department of Biology of the UFLA, and voucher specimens were deposited in the ESAL Herbarium at UFLA under the registration numbers 26946, 26947, 26945 and 26948, respectively.

The essential oils from fresh leaves were extracted by hydrodistillation using a modified Clevenger apparatus connected to a $4 \mathrm{~L}$ round-bottomed flask for a period of $2 \mathrm{~h}^{18}$. The hidrolacts were centrifuged for 5 minutes at $965 \mathrm{~g}$, and the oils were packaged in amber glass bottles and stored at a temperature of $4^{\circ} \mathrm{C}$.

\section{Identification and quantification of the essential oil constituents}

The GC-MS analyses was performed using a Perkin Elmer Autosystem XL gas chromatograph equipped with a fused silica DB-1 column (30 m x $0.25 \mathrm{~mm}$ ID, film thickness $0.25 \mathrm{~m}$; J \& W Scientific Inc.) coupled to a Perkin Elmer Turbomass mass spectrometer (software version 4.1). The oven temperature was programmed from 45 to $175^{\circ} \mathrm{C}$ at $3^{\circ} \mathrm{C} / \mathrm{min}$ and, subsequently, at $15^{\circ} \mathrm{C} / \mathrm{min}$ to $300^{\circ} \mathrm{C}$, where it was held for $10 \mathrm{~min}$.
The temperature of the transfer line was $280^{\circ} \mathrm{C}$; the temperature of the ionization chamber was $220^{\circ} \mathrm{C}$; the flow rate of the helium carrier gas was $30 \mathrm{~cm} / \mathrm{s}$; and the split ratio was 1:40. The identity of the compounds was determined by comparison of their retention indices and mass spectra with those of commercial standards and reference compounds present in oils existing in the laboratory and by comparing the spectra with a library of mass spectra developed in the laboratory of the Centre for Plant Biotechnology of the Faculty of Sciences, University of Lisbon.

The essential oils were analyzed by gas-liquid chromatography on a Perkin Elmer model 8700 gas chromatograph equipped with two flame ionization detectors (FID), a system for data processing and an automatic injector. Two columns of different polarity were installed with the following characteristics: DB-1 fused silica methylsilicone immobilized phase $(30 \mathrm{~m} \times 0.25 \mathrm{~mm}$ ID, film thickness $0.25 \mathrm{~m}$; J \& W Scientific Inc.); DB-17HT phenylmethylsilicone immobilized phase $(30 \mathrm{~m} \mathrm{x}$ $0.25 \mathrm{~mm}$ id). The oven temperature was programmed from $45^{\circ} \mathrm{C}$ to $175^{\circ} \mathrm{C}$ at $3^{\circ} \mathrm{C} / \mathrm{min}$ and, subsequently, at $15^{\circ} \mathrm{C} / \mathrm{min}$ to $300^{\circ} \mathrm{C}$, where the temperature was maintained for $10 \mathrm{~min}$. The temperatures of the injector and detector were $290^{\circ} \mathrm{C}$ and $280^{\circ} \mathrm{C}$, respectively. The flow rate of the hydrogen carrier gas was $30 \mathrm{~cm} / \mathrm{s}$, and the split ratio was 1:50. The percentage composition of the oils was determined by integration of peak areas without using correction factors. The values given represent the average of two injections ${ }^{19,15,20}$.

\section{Citrated human plasma}

Blood samples were obtained from the researchers involved in the work, in good health and with normal tests for BT (Bleeding Time), CT (Clotting Time), TPA (Time for Prothrombin Activation) and APTT (Activated Partial Thromboplastin Time). The samples were collected in BD Vacutainer ${ }^{\circledR}$ tubes containing 0.105 and 0.109 mol buffered sodium citrate $(3.2 \%)$, at a ratio of nine parts of blood to one part of citrate solution, as recommended by the CLSI (Clinical and Laboratory Standards Institute). This study was approved by the Committee of Ethics in Research with Humans of the UFLA and filed with the number 09978312.8.0000.5148.

\section{Snake venoms}

Desiccated Lachesis muta, Bothrops atrox and Bothrops moojeni venoms were purchased from 
Bioagents Serpentarium (Batatais, São Paulo, Brazil) and stored at $4^{\circ} \mathrm{C}$ until the time for preparation of solutions for use in the biological tests. The venoms were weighed and then dissolved in phosphate-buffered saline solution (PBS).

\section{Effects of the essential oils on clotting - induction or inhibition}

The coagulant potential of the essential oils was assessed as previously described (Selistre et al. 1990 $)^{21}$. Volumes of $200 \mu \mathrm{L}$ of citrated human plasma were maintained in a water bath at $37^{\circ} \mathrm{C}$, and two different volumes ( 0.6 and $1.2 \mu \mathrm{L})$ of essential oils were added, following by observation and measurement of time. The samples were gently shaken every $5 \mathrm{~min}$ for $45 \mathrm{~min}$. The incoagulability was defined as the absence of clotting after $24 \mathrm{~h}$ of observation. The inhibitory action of the essential oils on the coagulant activity induced by the venoms was also determined ${ }^{22}$. Pilot tests were performed for each venom to determine the dose necessery to clot $200 \mu \mathrm{L}$ of citrated plasma at $37^{\circ} \mathrm{C}$ withing 40 and 120 seconds (s).

Two interacting variables were evaluated: the first predicted the possible interaction between essential oil constituents and blood plasma components; the second considered the possible interaction between essential oil constituents and coagulating toxins present in the venoms. In the first test, prior incubation of the plasma $(200 \mu \mathrm{L})$ with different volumes of the essential oils $(0.6$ and $1.2 \mu \mathrm{L})$ was performed at $37^{\circ} \mathrm{C}$ for $15 \mathrm{~min}$, followed by the addition of $1 \mu \mathrm{L}(10 \mu \mathrm{g})$ of each venom solution $(L$. muta, B. atrox and B. moojeni) separately, and the time required for coagulation was measured. In the second test, different volumes of the essential oils $(0.6$ and $1.2 \mu \mathrm{L})$ were incubated with the snake venoms for $15 \mathrm{~min}$ at $37^{\circ} \mathrm{C}$, followed by the addition of plasma $(200 \mu \mathrm{L})$, and the time required for clot formation was measured.

\section{Fibrinogenolytic and the antifibrinogenolytic activities of the essential oils}

These activities were performed according to Czaikoski et al. (2010) ${ }^{23}$. Essential oils (0.6 and 1.2 $\mu \mathrm{L})$ were incubated with bovine fibrinogen $(60 \mu \mathrm{g})$ for $1.5 \mathrm{~h}$ at $37^{\circ} \mathrm{C}$ in a final volume of $25 \mu \mathrm{L}$ (PBS). The reactions were stopped by adding $10 \mu \mathrm{L}$ of bromophenol blue solution [Tris- $\mathrm{HCl} 0.05 \mathrm{~mol} / \mathrm{L}$, $\mathrm{pH} 8.0$, containing $10 \%(\mathrm{v} / \mathrm{v})$ glycerol, $10 \%(\mathrm{v} / \mathrm{v}) \beta$ mercaptoethanol, $2 \%(\mathrm{w} / \mathrm{v})$ sodium dodecyl sulfate (SDS) and $0.05 \%(\mathrm{w} / \mathrm{v})$ bromophenol blue] and heating of samples for $5 \mathrm{~min}$ at $100^{\circ} \mathrm{C}$. The samples were analyzed by polyacrylamide (acrylamide: bisacrylamide, 19:1) gel electrophoresis at $12 \%$ with $\mathrm{SDS}^{24}$. A control sample containing only fibrinogen ( $60 \mu \mathrm{g}$ in $25 \mu \mathrm{L}$ of PBS) was submitted to electrophoresis under the same conditions.

The inhibitory potential of the essential oils on the proteolysis induced by L. muta, B. atrox and $B$. moojeni venoms was assessed by SDS-PAGE [sodium dodecyl sulfate (SDS) polyacrylamide (PAGE)]. The essential oils (0.6 and $1.2 \mu \mathrm{L})$ and snake venoms $(30 \mu \mathrm{g})$ were pre incubated for 30 min at $37^{\circ} \mathrm{C}$ at first, followed by addition of fibrinogen molecules $(60 \mu \mathrm{g})$ and subsequent incubation for an additional $1.5 \mathrm{~h}$. In another assay, the essential oils and fibrinogen molecules were incubated for $30 \mathrm{~min}$ at $37^{\circ} \mathrm{C}$, followed by addition of snake venoms and subsequent incubation for an additional $1.5 \mathrm{~h}$.

\section{Statistical Analysis}

The experimental designs used for the clotting inhibition tests were completely randomized blocks in $2 \times 4$ factorial schemes ( 2 concentrations $\mathrm{x} 4$ essential oils), with three repetitions. The essential oils were compared with one another because they were extracted from species of the same botanical family. The significant factors determined by the Test F ( $\mathrm{p}<0.05)$ were subjected to the Scott-Knott Test of means $(5 \%)$ for determination of the models. The data were analyzed using the statistical program Sisvar ${ }^{25}$.

\section{RESULTS AND DISCUSSION}

The essential oils are mixtures of numerous compounds, with one or two major constituents, and their biological activities can be attributed to a synergic action among the molecules ${ }^{16}$. The variability in the constitution of essential oils is directly related to the species, and, within the same species, several factors can affect the composition, such as chemotype, location, collection period, and vegetative cycle, among others ${ }^{26}$. Considering the plant species used in this study the major constituents of the essential oils from fresh leaves of B. dracunculifolia are limonene (30.9\%), transnerolidol (22.4\%) and $\beta$-pinene (14.5\%), while those in the oil from $C$. bonariensis were limonene $(56.7 \%)$, trans- $\beta$-ocimene $(26.3 \%)$ and cisverbenol $(4.4 \%)$. The oil from $T$. diversifolia contained $\beta$-pinene $(38.3 \%)$, $\alpha$-pinene $(28.6 \%)$ and limonene $(8.8 \%)$ as the principal constituents ${ }^{20}$, and the main compounds found in the oil from $A$. 
polystachya were germacreme D (29\%), trans- $\beta$ ocimene $(14 \%)$ and $\beta$-caryophyllene $(10 \%)^{15}$. In the essential oils from species of the Asteraceae family, B. dracunculifolia, $C$. bonariensis, $T$. diversifolia and $A$. polystachya, previously characterized (97.3, 95.2, 99.7 and $97.3 \%$ of constituents identified, respectively), the high concentrations of terpenes stand out the monoterpenes predominated in the essential oils from $C$. bonariensis, $T$. diversifolia and $B$. dracunculifolia, and sesquiterpenes predominated in the essential oil from $A$. polystachya. The essential oils from $B$. dracunculifolia, $C$. bonariensis, $T$. diversifolia and A. polystachya contained 58.5, 92.2, 86.3 and $34.2 \%$ of monoterpenes, and 36.6, 5.1, 13.4 and $62.7 \%$ of sesquiterpenes, respectively ${ }^{20,15}$.

Among the pharmacological potentials, the antiophidian properties of the essential oils and its constituints from species of the Asteraceae family were partially evaluated in this work, for the first time. There is no mention of these essential oils in literature regarding their antiophidian properties. Snakebites represent a public health problem in Brazil, and the search for natural compounds that act effectively in neutralizing the local effects induced by toxins are of fundamental importance ${ }^{27}$ since the traditional antivenom has low effectiveness in counteracting local effects.

The essential oils ( 0.6 and $1.2 \mu \mathrm{L})$ assessed showed no clotting activity over a $24 \mathrm{~h}$ period. After prior incubation of venoms and oils, the clotting times (CT) obtained for L. muta and B. moojeni venoms increased significantly in the presence of all the essential oils (Table 1). The use of the essential oil from $C$. bonariensis extended the clotting time induced by $L$. muta venom from 52.2 to $115.2 \mathrm{~s}$ and that of B. moojeni from 108.3 to 2340.0 s. The dose of the essential oils was significant for the action of the oil from $T$. diversifolia against $L$. muta venom and that from $C$. bonariensis against B. moojeni venom.

Table 1. Clotting time of citrated human plasma. The essential oils from each species assessed (B. dracunculifolia, $C$. bonariensis, $T$. diversifolia, and $A$. polystachya), were previously incubated with each of venom from snake species (L. muta, B. moojeni and B. atrox)

Clotting time (s)

\begin{tabular}{cccc}
\cline { 2 - 4 } Essential oil $(\boldsymbol{\mu L})$ & L. muta $(\mathbf{1 0} \boldsymbol{\mu g})$ & B. moojeni $(\mathbf{1 0} \boldsymbol{\mu g})$ & B. atrox $(\mathbf{1 0} \boldsymbol{\mu g})$ \\
\hline Control & $52.2 \pm 0.5 \mathrm{Ab}$ & $108.3 \pm 0.4 \mathrm{Aa}$ & $100.8 \pm 2.0 \mathrm{Ab}$ \\
B. dracunculifolia $(\mathbf{0 . 6})$ & $82.8 \pm 2.6 \mathrm{Ca}$ & $184.8 \pm 2.4 \mathrm{Ba}$ & $143.5 \pm 1.7 \mathrm{Ca}$ \\
B. dracunculifolia (1.2) & $87.0 \pm 2.0 \mathrm{Ca}$ & $234.9 \pm 1.9 \mathrm{Ba}$ & $154.5 \pm 4.5 \mathrm{Da}$ \\
C. bonariensis (0.6) & $110.1 \pm 1.1 \mathrm{Aa}$ & $1977.9 \pm 50.6 \mathrm{Ab}$ & $191.1 \pm 0.6 \mathrm{Bb}$ \\
C. bonariensis (1.2) & $115.2 \pm 1.0 \mathrm{Aa}$ & $2340.0 \pm 52.9 \mathrm{Aa}$ & $264.0 \pm 2.4 \mathrm{Aa}$ \\
T. diversifolia $(\mathbf{0 . 6})$ & $75.6 \pm 1.7 \mathrm{Cb}$ & $283.5 \pm 3.8 \mathrm{Ba}$ & $207.9 \pm 1.9 \mathrm{Ab}$ \\
T. diversifolia $(\mathbf{1 . 2})$ & $91.2 \pm 1.8 \mathrm{Ca}$ & $315.6 \pm 2.6 \mathrm{Ba}$ & $227.7 \pm 2.7 \mathrm{Ba}$ \\
A. polystachya $(\mathbf{0 . 6})$ & $96.0 \pm 1.4 \mathrm{Ba}$ & $174.0 \pm 1.8 \mathrm{Ba}$ & $156.9 \pm 0.8 \mathrm{Cb}$ \\
A. polystachya $(\mathbf{1 . 2})$ & $99.9 \pm 1.8 \mathrm{Ba}$ & $188.4 \pm 8.3 \mathrm{Ba}$ & $180.0 \pm 2.1 \mathrm{Ca}$ \\
\hline
\end{tabular}

For each venom analyzed, the means followed by the same letter (uppercase for comparisons between essential oils and lower case for comparison of the concentrations), do not differ significantly at the 5\% probability by Scott-Knott Test. *The previous incubations, containing oils and venoms, were performed for $15 \mathrm{~min}$ at $37^{\circ} \mathrm{C}$, followed by the addition of plasma and measurement of time. 
The coagulant activity of $B$. atrox venom was inhibited by all the essential oils. The longest CTs were observed after incubation with $1.2 \mu \mathrm{L}$ of $C$. bonariensis and $T$. diversifolia. The clotting times increased from $100.8 \mathrm{~s}$ to $264.0 \mathrm{~s}$ and $227.7 \mathrm{~s}$, respectively.

The inhibitory effect of plant constituents on the clotting induced by venoms was also observed when the antiophidian activity of the aqueous extract of Bauhinia forficate L. leaves against $B$. moojeni and Crotalus durissus terrificus L. venoms was studied ${ }^{28}$. Previous incubation of the extract with the venom in different proportions (w/w) resulted in partial inhibition of clotting and $100 \%$ inhibition at a ratio of 1:200 (w/w). The extract of this plant was considered to be a promising source of natural inhibitors of serine proteases, the main enzymes involved in clotting disorders induced by snake venoms. In the present study, the inhibitory effect was observed for all the essential oils. The partial inhibitory effect observed for the oils can be related to the volumes employed, which were lower than those generally used in the tests involving aqueous extracts because of limitations of the method to the use of low-polarity compositions.

The venoms from L. muta, B. moojeni and B. atrox have different constitutions and, consequently, possess different mechanisms of action. However, all of them act on the blood clotting cascade, inducing clotting in the absence of calcium mainly due to the action of serineproteases ${ }^{29,5}$. Studies of the composition of all the essential oils evaluated demonstrated the presence of only terpenes, with individual variations in the contents of monoterpenes and sesquiterpenes ${ }^{15,20}$. The results obtained showed that the clotting induced by the venoms was inhibited largely by the essential oil from $C$. bonariensis, which has the highest content of monoterpenes $(92.2 \%)$ among the essential oils evaluated, indicating these compounds as potential enzyme inhibitors.

Tests employing prior incubation of the oils with plasma and subsequent addition of venoms were also conducted (Table 2) and, unlike the first incubation described, all the essential oils accelerated the clotting time induced by $L$. muta venom. No significant differences in the proclotting effects of B. dracunculifolia, C. bonariensis and A. polystachya were observed, but these effects were statistically lower than those observed for the oil from $T$. diversifolia.

The results suggest that there are interactions of plant compounds not only with snake venom toxins but also with blood plasma constituents which participate in the coagulation cascade.

Table 2. Clotting times for citrated human plasma. Different volumes of the essential oils from each species assessed (B. dracunculifolia, C. bonariensis, T. diversifolia and A. polystachya), were previously incubated with citrated plasma. The time was counted after the addition of each of venom from snake species (L. muta, B. moojeni and B. atrox)

Clotting time (s)

\begin{tabular}{cccc}
\cline { 2 - 4 } Essential oil $(\boldsymbol{\mu L})$ & L. muta $(\mathbf{1 0} \boldsymbol{\mu g})$ & B. moojeni $(\mathbf{1 0} \boldsymbol{\mu g})$ & B. atrox $(\mathbf{1 0} \boldsymbol{\mu g})$ \\
\hline Control & $45.0 \pm 1.5 \mathrm{Aa}$ & $114.3 \pm 2.7 \mathrm{Aa}$ & $106.5 \pm 0.9 \mathrm{Aa}$ \\
B. dracunculifolia $(\mathbf{0 . 6})$ & $39.6 \pm 1.5 \mathrm{Bb}$ & $117.0 \pm 0.6 \mathrm{Aa}$ & $106.8 \pm 2.4 \mathrm{Ba}$ \\
B. dracunculifolia $(\mathbf{1 . 2})$ & $33.0 \pm 0.6 \mathrm{Bb}$ & $114.6 \pm 1.8 \mathrm{Aa}$ & $87.6 \pm 0.5 \mathrm{Bb}$ \\
C. bonariensis $(\mathbf{0 . 6})$ & $34.2 \pm 0.8 \mathrm{Bb}$ & $117.9 \pm 1.2 \mathrm{Aa}$ & $84.3 \pm 0.9 \mathrm{Db}$ \\
C. bonariensis $(\mathbf{1 . 2})$ & $33.6 \pm 0.7 \mathrm{Bb}$ & $119.7 \pm 0.5 \mathrm{Aa}$ & $89.4 \pm 1.3 \mathrm{Bb}$ \\
T. diversifolia $(\mathbf{0 . 6})$ & $43.2 \pm 1.4 \mathrm{Aa}$ & $123.6 \pm 2.5 \mathrm{Aa}$ & $116.4 \pm 1.2 \mathrm{Aa}$ \\
T. diversifolia $(\mathbf{1 . 2})$ & $42.9 \pm 1.2 \mathrm{Aa}$ & $122.4 \pm 1.9 \mathrm{Aa}$ & $114.3 \pm 1.3 \mathrm{Aa}$
\end{tabular}


A. polystachya (0.6) $\quad 36.3 \pm 1.0 \mathrm{Bb} \quad 127.8 \pm 2.0 \mathrm{Aa} \quad 95.1 \pm 2.3 \mathrm{Cb}$

A. polystachya (1.2) $\quad 37.2 \pm 0.9 \mathrm{Bb} \quad 123.6 \pm 1.9 \mathrm{Aa} \quad 95.4 \pm 2.7 \mathrm{Bb}$

For each venom analyzed, the means followed by the same letter (uppercase for comparisons between essential oils and lower case for comparison of the concentrations), do not differ significantly at the $5 \%$ probability by Scott-Knott Test. *The previous incubations, containing oils and venoms, were performed for $15 \mathrm{~min}$ at $37^{\circ} \mathrm{C}$, followed by the addition of plasma and measurement of time.

The oil of T. diversifolia inhibited the coagulation, extending the plasma clotting time to statistically significant values (CT: $116.4 \pm 1.2$ for $0.6 \mu \mathrm{L}$ of oil; CT: $114.3 \pm 1.3$ for $1.2 \mu \mathrm{L}$ of oil). However, the oils from B. dracunculifolia (CT: $106.8 \pm 2.4$ and 87.6 \pm 0.5 for 0.6 and $1.2 \mu \mathrm{L}$, respectively), $C$. bonariensis (CT: $84.3 \pm 0.9$ and $89.4 \pm 1.3$ ) and $A$. polystachya $(\mathrm{CT}: 95.1 \pm 2.3$ and $95.4 \pm 2.7$ ) exhibited proclotting activity in the presence of the venom from $B$. atrox $(\mathrm{CT}: 106.5 \pm 0.9)$ under the same incubation conditions.

Torres and coworkers $(2011)^{13}$ observed that the ethanol extract of leaves from Nectandra angustifolia was effective in inhibiting the hemolytic and coagulant activities induced by Bothrops neuwiedi venom, whereas the essential oil from the same plant was only active against the coagulant effect. The authors analyzed the essential oil by GC and GC-MS and found $\alpha$-pinene, $\beta$ pinene and limonene. The same compounds were the predominant molecules in the essential oils evaluated in the present study. Ten ethanol extracts obtained from species belonging to different families inhibited $100 \%$ of the defibrinogenation and clotting induced by the $B$. asper venom when evaluated in vivo ${ }^{30}$.

The aqueous extract of leaves from Casearia sylvestris $\mathrm{Sw}$. (Flacourtiaceae) inhibited the proteases of venoms from various Bothrops species, neutralizing the hemorrhagic activity and partially inhibiting the coagutant effect and the proteolytic activity evaluated on the substrates casein and fibrinogen ${ }^{31}$. Although the aqueous extract of Mandevilla velutina has been primarily reported as an inhibitor of phospholipases $A_{2}$, the inhibitory potential against the hemorrhagic, fibrinogenolytic and caseinolytic activities, attributed mainly to proteases, has also been observed ${ }^{32}$. Thus, it's possible to conclude that plant molecules of different polarities present in extracts and oils interact with the different classes of enzymes present in the venoms, as well as with free molecules and animal cell components to protect them, resulting in partial or total inhibition of local symptoms of snakebites, especially those induced by Bothrops venoms.

Althought the potential of plants to inhibit different effects induced by toxins from snake venoms is being widely explored, most research involve extracts highlighting essential oils as mixtures of promising natural compounds to be explored.

Compounds isolated from species of Asteraceae with antiophidian properties have also been reported, such as the diterpeneclerodane (Bt-CD) isolated from Baccharis trimera (Less) DC, cynarin from Cynara scolymus L., wedelolactone, sitosterol, stigmasterol, d-mannitol and dimethylwedelolactone from Eclipta prostrate (Linn.) Linn, coumarin from Mikania glomerata (Sprengel), silymarin from Silybum marianum (L.) Gaertn, and caffeic and chromogenic acid derivatives from Vernonia condensata Baker. Although there are reports of proteins and steroids with antiophidian properties, these properties most noticable in phenolic compounds (flavonoids, cumestans, pterocarpans, nitro-compounds, tannic acid and others) and terpenes (mainly diterpenes and triterpenes) $)^{14}$.

Mendes et al. (2008) $)^{2}$ assessed the antiophidian potential of the aqueous extract of Schizolobium parahyba (Vell.) Blake (Family: Fabaceae Caesalpinoideae) and found that the clotting induced by $B$. pauloensis venom required eight times as long in a 1:50 w/w proportion. However, very weak inhibition was observed when the clotting was induced with $C$. durissus terrificus venom.

In the present study the inhibitory activity of the essential oils against Bothrops venoms was higher than that observed for Crotalus (results not shown), reinforcing the hypothesis of the occurrence of a specific interaction between oil compounds and proteins present in the venoms from different snake species.

A variety of synergistic interactions between the molecules could be better exploited in future studies using standards corresponding to major 
compounds, both separately or in mixtures that simulate the composition of the oils.

Fibrinogen is a dimeric glycoprotein of $340 \mathrm{kDa}$ present in the blood. It consists of polypeptide chains $(\alpha, \beta$ and $\gamma)$ with molecular weights of 66.5 , 52 and $47 \mathrm{kDa}$, respectively ${ }^{33}$. Fibrinogen molecules have been widely used as substrates to evaluate the proteolytic effect induced by venoms related to hemorrhagic and/or thrombolytic activities, because isolated proteases may be coagulants, anticoagulants or proclotting ${ }^{34}$.

These essential oils from $B$. dracunculifolia, $C$. bonariensis, $T$. diversifolia and $A$. polystachya, previously incubated with fibrinogen solution, did not induce cleavage or differential migration of the fibrinogen chains $(\alpha, \beta$ and $\gamma)$ in the analyses performed by polyacrylamide gel electrophoresis. However, some molecules of fibrinogen incubated with the essential oils could have resisted the reduction induced by $\beta$-mercaptoethanol and heating at $100^{\circ} \mathrm{C}$ for $5 \mathrm{~min}$. On the other hand, samples that have not penetrated the gel may be artifacts of fibrinogen molecules that interacted with constituents of the oils, which could prevent their migration. Some examples of the effect observed during the analysis can be viewed in Figure 1A.

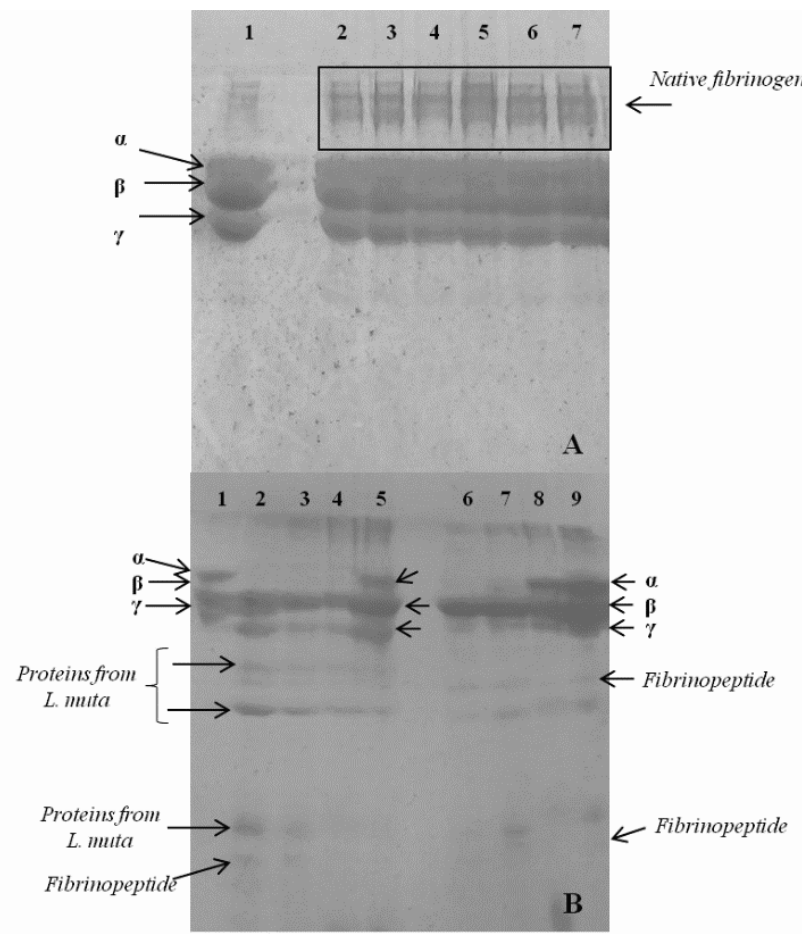

Figure 1. SDS-PAGE for visualization of fibrinogenolytic activity.

(A) Samples: 1- Fibrinogen $(60 \mu \mathrm{g})$; 2- Fibrinogen + EO from $C$. bonariensis $(0.6 \mu \mathrm{L})$; 3 - Fibrinogen + EO from
T. diversifolia $(0.6 \mu \mathrm{L})$; 4- Fibrinogen + EO from $B$. dracunculifolia $(0.6 \mu \mathrm{L}) ; 5$ - Fibrinogen + EO from $B$. dracunculifolia $(1.2 \mu \mathrm{L})$; 6- Fibrinogen + EO from $A$. polystachya $(0.6 \mu \mathrm{L}) ; 7$ - Fibrinogen + EO from $A$. polystachya $(1.2 \mu \mathrm{L})$.

(B) Samples: 1- Fibrinogen $(60 \mu \mathrm{g})$; 2 - Fibrinogen $+L$. muta venom $(30 \mu \mathrm{g})$ (30 $\mathrm{min}$ of incubation); 3Fibrinogen + L. muta (60 min of incubation); 4- L. muta venom + EO from B. dracunculifolia $(1.2 \mu \mathrm{L})+$ Fibrinogen ; 5- Fibrinogen + EO from B. dracunculifolia +L. muta venom ; 6- Fibrinogen + B. moojeni venom (30 min of incubation); 7- Fibrinogen $+B$. moojeni venom (60 min of incubation); 8- B. moojeni venom + EO from A. polystachya $(1.2 \mu \mathrm{L})+$ Fibrinogen ; 9- Fibrinogen + EO from A. polystachya $+B$. moojeni venom . The order of presentation of the items that make up the samples corresponds to the sequence of addition of these to the incubation medium.

L. muta, B. moojeni and B. atrox venoms were used as sources of proteolytic agents to induce principally the cleavage of the alpha chain of fibrinogen molecules (Figure 1B). The fibrinogenolytic activity of $B$. atrox venom was not inhibited by the essential oils from $B$. dracunculifolia, C. bonariensis, T. diversifolia or A. polystachya. Cintra and coworkers ${ }^{4}$ described that Batroxase, a metalloproteinase with high fibrinogenolytic and thrombolytic activities present in the same venom, is probably one of the enzymes responsible for the proteolysis observed, which was not inhibited in the present study ${ }^{4}$.

Tests using different volumes of oils, incubation times, run times, concentrations of polyacrylamide in the gel and variations of the staining times in the presence of Coomassie Brilliant Blue (results not shown) resulted in the hypothesis that the fibrinogen molecules could be interacting with constituents of the oils, making it impossible to bind the dye with fibrinogen molecules. Coomassie Brilliant Blue interacts with protein macromolecules containing amino acids side chains with a basic or aromatic character. Several substances can interfere in these interactions, including polyphenols and polyphenol oxidases ${ }^{35}$, which could present binding mechanisms similar to those of the molecules present in the essential oils evaluated in the present work.

The fibrinogenolysis induced by $L$. muta venom was only inhibited when the $B$. dracunculifolia oil was previously incubated with fibrinogen, with subsequent addition of the venom (Figure 1B, sample 5). It is suggested that molecules of the sesquiterpene fraction of this oil (36.6\%) protect the 
fibrinogen molecules against the action of proteases present in $L$. muta venom.

The essential oil from A. polystachya proved to be effective in inhibiting the fibrinogenolytic activity induced by $B$. moojeni venom in trials involving prior incubation with fibrinogen or venom (Figure $1 \mathrm{~B}$, samples 8 and 9 , respectively). The fact that the $B$. dracunculifolia oil inhibited the activity of $L$. muta venom, and the oil from A. polystachya only inhibited that of $B$. moojeni venom, indicates the presence of specific and not random interactions, considering the wide composition range and diversity of homologous proteins present in snake venoms. This hypothesis is in agreement with observations made previously by other authors about plants with antiophidian properties ${ }^{2}$.

These observations indicate the possibility that the essential oil components from A. polystachya, mostly sesquiterpenoids (62.7\%), connect efficiently with fibrinogen, thereby reducing the fibrinogenolysis induced by the venom. In addition, incubation of $A$. polystachya with $B$. moojeni venom and evaluation of the results by SDS-PAGE confirmed the interactions of compounds present in the oils with proteins present in the venoms. Bands with molecular weights corresponding to that of phospholipases $\mathrm{A}_{2}$ were observed after staining, but not those corresponding to proteases (results not shown).

A $100 \%$ inhibition of the fibrinogenolytic activity of Bothrops venoms was observed by Vale and coworkers, after incubation with an aqueous extract of Shizolobium parahyba ${ }^{11}$. These authors suggested the presence of interactions between tannins and proteins and related that they are influenced by the number of these molecules present in the reaction medium, as well as by the $\mathrm{pH}$ and ionic strength of the medium ${ }^{35}$. Thus, future studies evaluating variations in the reaction medium during the incubations of essential oils with snake venoms would make it possible to define more efficiently the mechanisms of these inhibitory effects.

\section{CONCLUSIONS}

The compositions of essential oils from $C$. bonariensis and $T$. diversifolia, composed predominantly by monoterpenes, are very different from those of the most active essential oils $(B$. dracunculifolia and A. polystachya). Thus, considering the variations in oil composition and the enzyme composition of the venoms, the changes in the activities evaluated may be related to specific interactions between monoterpenes and sesquiterpenes and proteases from snake venom. Metalloproteases belonging to different classes and presenting distinct structural domains, such as disintegrin and lectin simile, and also serineproteases, are molecules that are possibly involved in interactions with constituents of essential oils.However, the oils evaluated presented some relevant therapeutic properties because they allinhibited the clotting and fibrinogenolysis induced by the venoms.Considering the low degree of effectiveness of traditional serotherapy in the treatment of the local effects induced by snakebites, the essential oils hold promise for topical use as potential inhibitors of venom toxins. The oils, in general, do not require specific pharmaceutical preparations and could have direct applications soon after extraction. Many oils with antimicrobial, anti-inflammatory and healing properties are described in the literature, and these actions are of great value in the treatment of snake envenomations. Further studies on the isolation of constituents of these oils and the elucidation of the mechanisms of interaction between secondary metabolites, venom proteins and animal proteins are essential for the development of new antiophidian therapies and to establish the ideal conditions for the application of essential oils.

\section{ACKNOWLEDGEMENTS}

The authors thank the support of the Conselho Nacional de Desenvolvimento Científico e Tecnológico (CNPq), the Fundação de Amparo a Pesquisa do Estado de Minas Gerais (FAPEMIG), and the Universidade Federal de Lavras and Pest OE/EQB/LA0023/2011.

\section{REFERENCES}

1- Morais NCG, Mamede CCN, Fonseca KC, Queiroz MR, Gomes-Filho SA, Santos-Filho NA, et al. Isolation and characterization of moojenin, an acidactive, anticoagulant metalloproteinase from Bothrops moojeni venom. Toxicon. 2012; 60(7): 1251-1258.

2- Mendes MM, Oliveira CF, Lopes DS, Vale LHF, Alcântara TM, Izidoro LFM, et al. Anti-Snake Venom Properties of Schizolobium parahyba (Caesalpinoideae) Aqueous Leaves Extract. Phytother. Res. 2008; 22: 859-866. 
3- Dravidamani S, Whitaker R, Andrews H. The Irula tribal snake venom extraction co-operative. Part III [Online], 2008.

4- Cintra ACO, De Toni LGB, Sartim MA, Franco JJ, Caetano RC, Murakami MT, et al. Batroxase, a new metalloproteinase from Bothrops atrox snake venom with strong fibrinolytic activity. Toxicon. 2012; 60(1): 70-82.

5- Sanz L, Escolano J, Ferretti M, Biscoglio MJ, Rivera E, Crescenti EJ, et al. Snake venomics of the South and Central American Bushmasters. Comparison of the toxin composition of Lachesis muta gathered from proteomic versus transcriptomic analysis. $J$. Proteomics. 2008; 71(1): 46-60.

6- Cavalcante WL, Campos TO, Dal Pai-Silva M, Pereira PS, Oliveira CZ, Soares AM, et al. Neutralization of snake venom phospholipase A2 toxins by aqueous extract of Casearia sylvestris (Flacourtiaceae) in mouse neuromuscular preparation. J. Ethnopharmacol. 2007; 25; 112(3): 490-497.

7- Marcussi S, Sant'Ana CD, Oliveira CZ, Rueda AQ, Menaldo DL, Beleboni RO, et al. Snake Venom Phospholipase A2 Inhibitors: Medicinal Chemistry and Therapeutic Potential. Curr. Top. Med. Chem. 2007; 7(8): 743-756.

8- Diogo LC, Fernandes RS, Marcussi S, Menaldo DL, Roberto PG, Matrangulo PV, et al. Inhibition of snake venoms and phospholipases $\mathrm{A}(2)$ by extracts from native and genetically modified Eclipta alba: isolation of active coumestans. Basic Clin. Pharmacol. Toxicol. 2009; 104(4): 293-299.

9- Da Silva ML, Marcussi S, Fernandes RS, Pereira PS, Januário AH, França SC, et al. Anti-snake venom activities of extracts and fractions from callus cultures of Sapindus saponaria. Pharm. Biol. 2012; 50(3): 366-375.

10- Vásquez J, Jiménez SL, Gómez IC, Rey JP, Henao AM, Marín DM, et al. Snakebites and ethnobotany in the Eastern region of Antioquia, Colombia-the traditional use of plants. J. Ethnopharmacol. 2013. 146(2): 449-455.

11- Vale LHF, Mendes MM, Hamaguchi A, Soares AM, Rodrigues VM, Homsi-Brandeburgo MI. Neutralization of Pharmacological and Toxic Activities of Bothrops Snake Venoms by Schizolobium parahyba (Fabaceae) Aqueous Extract and Its Fractions. Basic Clin. Pharmacol. Toxicol. 2008; 103: 104-107.

12- Salazar AM, Vivas J, Sánchez EE, RodríguezAcosta A, Ibarra C, Gil A, Carvajal Z, et al. Hemostatic and toxinological diversities in venom of Micrurus tener tener, Micrurus fulvius fulvius and Micrurus isozonus coral snakes. Toxicon. 2011; 58(1): 35-45

13- Torres AM, Camargo FJ, Ricciardi GA, Ricciardi AI, Dellacassa E. Neutralizing effects of Nectandra angustifolia extracts against Bothrops neuwiedi snake venom. Nat. Prod. Commun. 2011; 6(9): 1393-1396.

14- Soares, AM, Ticli FK, Marcussi S, Lourenço MV, Januário AH, Sampaio SV, et al. Medicinal plants with inhibitory properties against snake venoms. Curr. Med. Chem. 2005; 12(22): 2625-41.

15- Miranda CASF, Cardoso MG, Carvalho MLM, Figueiredo ACS, Nelson DL, Oliveira CM, et al. Chemical Composition and Allelopathic Activity of Parthenium hysterophorus and Ambrosia polystachya Weeds Essential Oils. Am. J. Plant Sci. 2014; 5: 1248-1257.

16- Silva CB, Simionatto E, Hess SC, Peres MTLP, Simionatto EL, Wisniewski Júnior A, et al. Composição química e atividade alelopática do óleo volátil de Hydrocotyle bonariensis Lam (Araliaceae). Quim. Nova. 2009; 32( 9): 2373-2376.

17- Verdi LG, Brighente IMC, Pizzolatti MG. Gênero Baccharis (Asteraceae): aspectos químicos, econômicos e biológicos. Quim. Nova. 2005; 28(1): 85-94.

18- Farmacopeia Brasileira. $4^{\mathrm{a} e d}$., parte I, São Paulo: Ateneu; 2000.

19- Mendes MD, Lima AS, Trindade H, Correia AID, Barroso JG, Pedro LG, et al. ISSR molecular characterization and leaf volatiles analysis of Pittosporum undulatum Vent. naturalized in the Azores archipelago (Portugal). Ind. Crops Prod. 2011; 33(3): 710-719.

20- Miranda CASF, Carvalho MLM, Gomes MS, Santiago JA, Santiago WD, Teixeira ML, et al. Evaluation of the chemical composition and allelopathic potential of essential oils from three species of Astereceae against seed germination and seedling vigor of lettuce. J. Adv. Pharm. Chem. 2015; 11(6): 3669-3677.

21- Selistre HS, Queiroz LS, Cunha OA, De Souza GE, Giglio JR. Isolation and characterization of hemorrhagic, myonecrotic and edema-inducing toxins from Bothrops insularis (jararaca ilhoa) snake venom.Toxicon. $1990 ; 28(3)$ : 261-73.

22- Valentin E, Lambeau G. What can venom phospholipases $\mathrm{A}_{2}$ tell us about the functional diversity of mammalian secreted phospholipases $\mathrm{A}_{2}$ ? Biochemie. 2000; 82: 815-831.

23- Czaikoski PG, Menaldo DL, Marcussi S, Baseggio AL, Fuly AL, Paula RC, et al. Anticoagulant and fibrinogenolytic properties of the venom of Polybia occidentalis social wasp. Blood Coagulation Fibrinolysis. 2010; 21(7): 653-659.

24- Laemmli UK. Cleavage of structural proteins during the assembly to the head of bacteriophage T4. Nature. 1970; 227: 680-685.

25- Ferreira DF. Sisvar: a computer statistical analysis system. Cien. Agrotecnol. 2011; 35(6): 1039-1042. 
26- Gobbo-Neto L, Lopes N P. Plantas medicinais: fatores de influência no conteúdo de metabólitos secundários. Quim. Nova. 2007; 30(2): 374-381.

27- Domingos TFS, Moura LA, Carvalho C, Campos VR, Jordão AK, Cunha AC, et al. Antivenom Effects of 1,2,3-Triazoles against Bothrops jararaca and Lachesis muta Snakes. BioMed Res. Int. 2013, 2013, 7 pages.

28- Oliveira CZ, Maiorano VA, Marcussi S, Sant'Ana $\mathrm{CD}$, Januário $\mathrm{AH}$, Lourenço $\mathrm{MV}$, et al. Anticoagulant and antifibrinogenolytic properties of the aqueous extract from Bauhinia forficata against snake venoms. J. Ethnopharmacol. 2005; 98: 1-2.

29- Queiroz GP, Pessoa LA, Portaro FCV, Furtado MFD, Tambourgi DV. Interspecific variation in venom composition and toxicity of Brazilian snakes from Bothrops genus. Toxicon. 2008; 52(8): 842851.

30- Núñez V, Cid P, Sanz L, Torre P de La, Angulo Y, Lomonte B, et al. Snake venomics and antivenomics of Bothrops atrox venoms from Colombia and the Amazon regions of Brazil, Peru and Ecuador: geographic variation of venom phenotype by paedomorphism. J. Proteomics. 2009; 73: 57-78.

31- Borges MH, Soares AM, Rodrigues VM, Oliveira F, Fransheschi AM, Rucavado A, et al. Neutralization of proteases from Bothrops snake venoms by the aqueous extract from Casearia sylvestris (Flacourtiaceae). Toxicon. 2001; 39(12): 1863-1869.
32- Biondo R, Pereira AMS, Marcussi S, Pereira PS, França SC, Soares AM. Inhibition of enzymatic and pharmacological activities of some snake venoms and toxins by Mandevilla velutina (Apocynaceae) aqueous extract. Biochimie. 2003; 85(10): 1017 1025.

33- Monaco S, Gioia M, Rodriguez J, Fasciglione GF, Pierro DD, Giulio L, et al. Modulation of the proteolytic activity of matrix metalloproteinase-2 (gelatinase A) on fibrinogen. Biochem J. 2007; 15(402): 503-513.

34- Zaia DAM, Zaia CTBV, Lichtig J. Determinação de proteínas totais via espectrofometria: vantagens e desvantagens dos métodos existentes. Quim. Nova. 1998; 21(6): 787-793.

35- Simões CMO, Schenkel EP, Gosmann G, Mello JCP, Mentz LA, Petrvick PR. Farmacognosia: da planta ao medicamento. 6th ed. Florianópolis: Editora da UFSC; 2007.

Received: January 15, 2016; Accepted: April 25, 2016 